\author{
Inha Ziankova \\ Ph.D.(Economics), Associate Professor \\ Polotsk State University \\ 29 Blokhin Str., 211440, Novopolotsk, Vitebsk region, Belarus \\ E-mail: i.zenkova@psu.by, ORCID: https://orcid.org/0000-0002-6978-5446 \\ Halina Yaryhina \\ Assistant, Postgraduate student \\ Polotsk State University \\ 29 Blokhin Str., 211440, Novopolotsk, Vitebsk region, Belarus \\ E-mail: g.yarygina@psu.by \\ Rabih Said Sati \\ Postgraduate student \\ Polotsk State University \\ 29 Blokhin Str., 211440, Novopolotsk, Vitebsk region, Belarus \\ E-mail: rabih.sati67@gmail.com
}

\title{
GLOBAL ENERGY SECURITY AND INTERNATIONAL ECONOMIC DEVELOPMENT
}

\begin{abstract}
Energy security is at the top of the international political and economic agenda due to its importance for the economic and social development of individual countries, for relations between them, for the global economy and the environment. Indeed, it is difficult to imagine an area where countries are more interdependent than at the confluence of energy, environment, and economic development. Energy security has implications for domestic and foreign policy. This means the interdependence between producer and consumer, where mutual vulnerability and a win-win opportunity are short-term and long-term. The work systematizes the types of energy with the goal of sustainable development: the balance of economic, social, and environmental components, through a model of a circular economy, which allows achieving energy security. The first step is switching from carbon-based energy (oil, gas, coal) to clean energy (solar, wind, hydropower, etc.). However, it is also important to act on the principle of energy efficiency, which is to measure the difference between the actually used energy and the total energy consumed (often higher due to losses). The principle of the circular economy of achieving the most efficient use of resources is the most essential for the development of innovative solutions aimed at the transition to clean energy. Having studied the various approaches by comparison and analogy, we can conclude that the Concept of the circular economy offers effective business models to ensure environmentally friendly resource use, contributing to the achievement of sustainable development goals of society. The article used historical and statistical methods, as well as a system approach to the study of economic phenomena, which helped to identify the relationship between all elements and their roles in the general functioning of the circular economy. Using the method of comparison and scientific modeling, the role of the circular economy in resource-saving, minimizing waste and reducing pressure on the environment is revealed, while achieving significant economic and social results in energy security.

Keywords: energy security, circular economy, resources, energy, ecology.

JEL Classification: P48, Q43, Q56, Q57.
\end{abstract}

Introduction. Global energy security and sustainability in the 21 st century will be less dependent on the total world population than on incomes and their distribution. This, in turn, will depend to a large extent on how effectively the problem of the lack of energy services, which currently limit economic opportunities in less developed regions, is addressed. In addition, energy security will depend on the ability of countries to maintain reliable energy sources to meet their needs.

As the economy develops, the energy needs and priorities of countries change. The evolution of demand at different stages of economic development is changing. As the economy develops, as happened with industrialized countries, there is a tendency to introduce more efficient technologies for the provision of energy services, and the structure of economic activity changes, since energy intensity tends to decrease over time (Воропай, 2005).

\footnotetext{
${ }^{\odot}$ Yaryhina H., Ziankova I., Said Sati R., 2020
} 
Prices play several significant roles in economic production and demand. Most importantly, prices send signals to buyers and sellers. However, it is important to distinguish between prices and costs. There are four types of costs: cash costs, opportunity costs, environmental and healthcare costs, and socio-political costs. Most consumers are mostly prone to cash costs and less to others, although they are also important.

Renewable energy technologies, energy efficiency, advanced energy technologies and related products and services are among the fastest growing investment sectors in recent years, with large developing countries becoming investment leaders, not just technology transfer followers. Despite this progress, total public and private funding for energy-related research, development and deployment remains far less than the amount needed to move to a sustainable, climate-limited world.

Due to their important role in job creation and economic growth, small and medium-sized enterprises are potential leaders in transforming business models in many parts of the world (Макаров, 1998).

The purpose and tasks. The purpose of this article is to study the aspects of energy security. Lack of fossil fuels as energy sources, which implies compromises in terms of replacement with renewable energy sources using the principles of a circular economy, while taking into account the social and environmental consequences of specific energy sources. The development of reliable, continuous, affordable and environmentally sound provision of energy services, combined with an emphasis on energy efficiency and energy conservation, is the only way to mitigate the various multilevel aspects of energy security.

For this, the following tasks were set:

1) to consider various approaches and definitions of energy security at different stages;

2) consider energy sources at the present stage;

3) to analyze the global consumption of oil and gas, coal, lignite;

4) to analyze the economy of nuclear energy and its future prospects;

5) consider ways of using fuel and energy resources and renewable energy sources as a possible way to increase resource efficiency (solar energy, wind energy, biomass energy, geothermal energy, hydropower);

6) identify the positive effects of green and circular economies;

7) determine the ability of the environment to absorb contaminated waste;

8) Consider and analyze possible future energy.

Energy security. Energy security may be defined as a partial match between economic security, national security and environmental security.

In fact, economic security can mean creating new jobs or searching for product markets. The idea of national security is that lower energy demand will affect our sense of global security. Environmental safety includes the link between air pollution and health, as well as greenhouse gas emissions and global warming. Moreover, economic security is the security that generates security resources, and within it, energy security is one of the fundamental prerequisites for the normal functioning of the state and the achievement of the welfare of its citizens, which can be transferred to the global level (Popescu, 2015).

Preserving our environment and reducing our dependence on raw materials and energy require a profound transformation of our production and consumption processes, which would not be possible without using the concept of a circular economy. The areas of optimal energy transformation, waste management and water treatment are the triptych on which our economy and the ecological balance of our territories, as well as our planet as a whole, are based.

According to experts from the International Energy Agency (IEA), energy security is a comprehensive concept whose goal is to protect consumers from supply disruptions caused by emergencies, terrorism or inadequate investment in energy market infrastructures. Recently, the greatest attention has been paid to such key issues as international cooperation, optimal organization of markets and unification of the conditions for consumers to access global energy resources.

According to the average forecast scenario of the UN organization, the world population will grow from 6.2 billion people (at the beginning of the XXI century) to 8 billion by 2030 and up to 10 billion people by 2050 , with $80 \%$ of the population Live in developing countries. The population of the Earth significantly affects energy consumption, but more energy balance depends on the pace of industrial development. For example, in the XX century. The world's population has grown by 3.6 
times, while the global energy balance has increased by more than 10 times. The gigantic energy needs were determined by the intensive development of industry mainly in Europe, the United States and Russia.

If other countries of the world developed in recent decades according to a similar scenario, the volume of oil, gas and coal production was many times higher than the current level. For the countries of Southeast Asia in the medium term, extremely high economic growth rates are projected - up to $4 \%$ per year. The leader is currently China with an annual growth of $9 \%$. It would be impossible to provide energy for such an economic growth using the technologies of the 20th century. That is why innovative technologies in the energy sector are becoming crucial in the world. In most developing countries, the current lifestyle does not yet require the same energy costs per capita as in Europe or the USA, but by the middle of the 21 st century. As a result of industrialization of the economy, these countries will consume half of the global energy balance (Мазур, 2008).

For most professionals, energy security means the necessary energy production in their own country and minimal dependence on foreign imports. However, energy security includes three aspects: providing alternative sources of supply, determining alternative energy routes and ensuring the safety of existing sources and transportation networks (Circular Economy Action Plan).

In March 2019, the European Commission reported on the implementation and progress of key initiatives of its Action Plan for 2015 in the "Report on the Implementation of the Circular Economy Action Plan". Three years after the adoption of the 'Plan of Action for the Circular Economy' is fully completed. His 54 activities were completed, even if work on some of them continues after 2019.

High-level commitments and long-term commitments are key to the development of a circular economy in the EU. This commitment led to the endorsement of the EU Circular Economy Action Plan, with the benefits of including and working in various policy areas to support its implementation. This is also reflected in the growing number of financing opportunities for specific projects. Engaging a wide range of actors from the public and private sectors is critical to a successful transition to a circular economy. The mobilization of these actors and the establishment of strong partnerships may require significant efforts, since this process entails the development of circular economy strategies in various sectors and at different levels of activity.

These initiatives have three clear objectives:

1. Politics: expand cooperation between the EU and third countries in the field of environmental policy by signing political agreements that promote the development of a circular economy, environmentally friendly public procurement and innovative, sustainable and inclusive growth;

2. To gain a better understanding of the environmental problems that third countries face;

3. Support green European companies (especially SMEs), expand their activities abroad and promote green solutions through business partnerships.

Discussions in circular economic missions focus on topics related to eco-innovation, chemicals and plastics, waste, water management, marine pollution, and urban best practices.

The circular economy provides pragmatic and effective solutions for the gradual depletion of vital resources for the functioning of the modern economy. Closing the cycles of materials, water and energy, this "other" economy allows the economy to grow, while reducing extraction from nature.

The circular economy multiplies the productivity of the resources extracted by nature: therefore, it meets the goals set by the EU in terms of efficient use of resources. It is aimed not only at the optimal use of water and raw materials, but also at energy resources.

With regard to energy policy, today the priority is to achieve greater coherence between the overall goals of mitigating climate change and energy security and independence. Energy efficiency is the most effective means of combining the decarbonization of the economy and enhancing EU energy security. The potential for reducing fossil fuel consumption through energy efficiency policies is much greater than replacing these fossil energy sources with other renewable energy sources. Such policies can also contribute to the development of new types of economic activity in member states and at the local level in European regions and cities, thereby creating new pools of long-term jobs, stimulating growth and reducing energy dependence. Nevertheless, energy efficiency as a fundamental instrument of policy and strategy is not sufficiently taken into account by European and national politicians.

At the EU level for 2020, a mandatory goal was set - to achieve $20 \%$ energy savings. The EU is likely to miss it by $1 \%$ only if its targets for CO2 emissions and renewable energy sources (for which mandatory targets were set in 2008) are exceeded. The benefits of a binding approach are therefore 
tangible and a valuable lesson for policy makers who are responsible for defining policies for the post-2020 regime. In times of economic and energy crisis, energy efficiency combined with diversification of energy sources can help solve current difficulties in the context of the recent Ukrainian and Russian crisis («Circular economy and», 2014).

Energy is not taken into account by economic theorists who write books and develop economic models, except in rare cases, since they rely on a theory that speaks of the role of energy as an engine of economic growth with its share in the total budget of each country, since the prevailing economic models consider That economic growth depends on demand. A consumer who is connected with the reality of the population, that is, with the availability of labor, in addition to investing mainly in savings, the problem is that most of these models neglect the role of energy and are not considered an essential factor in production.

Given the low contribution of the energy sector to GDP of less than 5 percent over the past 25 years, it does not fall under the calculation of economic models adopted by institutions such as Cooperation and Economic Development or the International Monetary Fund, since it believes that the growth is due to the availability of cash.

Energy problems make up a small proportion of analyzes and articles in the international press, except in the case of crises in the Middle East, therefore, it is believed that money is the basis of the economic movement in the world, but capital is inefficient and productive without activating the role of energy, as the availability of labor. Thus, energy is the basis of the movement of the world.

Sources of energy at the present stage. An analysis of many studies shows that the potential of the Earth's natural resources can provide humanity with energy for the long term. Oil and gas have a fairly powerful resource, but this "golden fund" of the planet must not only be rationally used in the 21 st century, but also be preserved for future generations. But also an analysis of other studies shows that in the future we can expect that oil production will peak and consumption and prices will continue to grow, disputes and conflicts over limited resources will increase and become a constant issue on the international community's security agenda. The risk of conflicts based on gaining access and control over the exploitation of energy resources will remain high.

The energy sector should be a dynamic sector that actively supports the development of the global economy and helps reduce imbalances between countries. In this regard, the overall goal of the global energy strategy is to meet current, medium and long-term energy needs in the energy sector at affordable prices that are most suitable for a modern market economy with a decent standard of living, in terms of quality and safety. In this case, the principles of sustainable development must be taken into account. Thus, due to common goals, which are aimed at ensuring security, maintaining a balance between the import of primary energy resources and the rational efficient use of national reserves based on commercial and economic factors, it represents a priority for the further development of safe and competitive energy.

Oil and gas consumption. The energy sector in all countries plays a vital role in socio-economic development. Oil and gas revenues are the main source of income in most countries.

Oil is still the most important natural resource in the Arab world, and all possibilities indicate that this situation will continue in the foreseeable future. Huge oil reserves (such as shale oil in the United States, oil sands in Canada, coal gas in Australia, and deep-sea areas in Brazil).

World crude oil production rose $(+2 \%)$ due to explosive growth in the United States $(+16.5 \%)$. In June 2018, OPEC members agreed to increase oil production to prevent supply shortages and lower prices after previous production cuts were deemed excessive and prices too high. This stabilized world prices before they rose again pending US sanctions on Iranian oil exports. Crude oil production in the United States has increased significantly due to increased exploration and production of oil from rich shale reserves, which has led to the largest annual increase in production for one country in history. This is due to the launch of new projects, steady demand for oil and higher prices ( $\$ 14$ per barrel higher than in 2017). Oil production continued to grow in Russia, the Middle East (with the exception of Iran) and Africa. Latin America, on the other hand, experienced a general decline. Venezuelan political problems, compounded by US sanctions, have led to a $29 \%$ drop in oil production, equivalent to one-third of US production growth. Similarly, Iranian oil production fell by $7 \%$ after the restoration of international sanctions (Figure 1) (Statistical Yearbook of World Energy, 2019). 


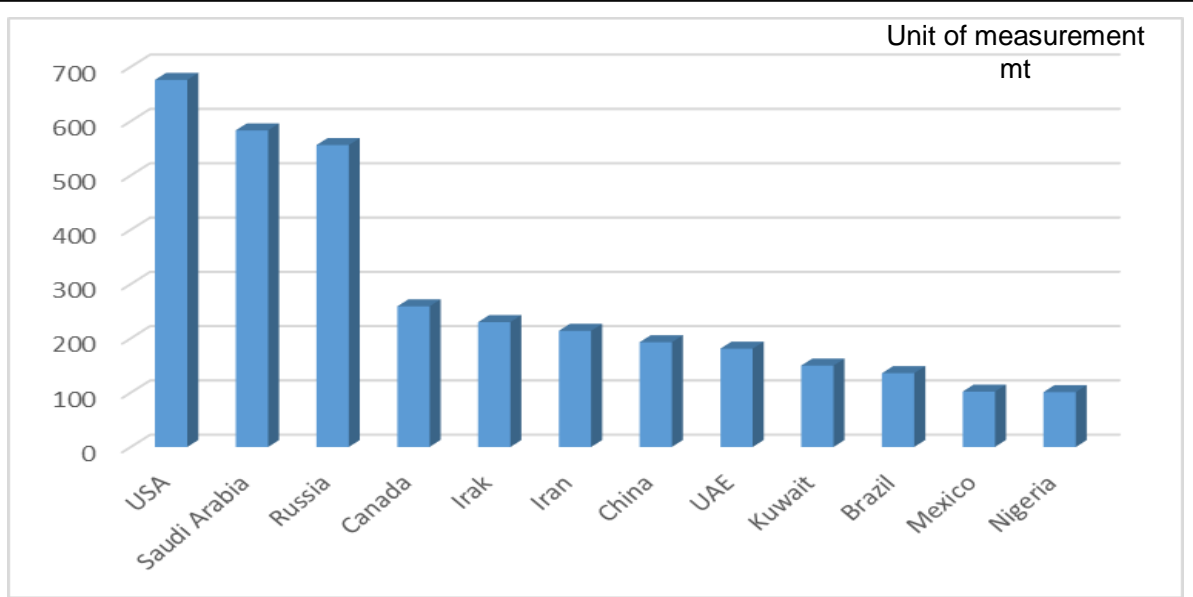

Figure 1.

Source: own development based on the data (Statistical Yearbook of World Energy, 2019)

Gas. The USA and China contributed to an increase in global consumption of natural gas (+ 5\%). World gas consumption in 2018 accelerated thanks to the efforts of the United States and China, which accounted for about two-thirds of additional consumption. In 2018, gas demand in the United States grew by $10 \%$, which was the highest growth rate in the last 30 years, stimulated by the electric power industry ( $+15 \mathrm{GW}$ of new gas power plants) and construction. Gas consumption also accelerated in China (+ 18\%) in accordance with the policy of substituting coal for gas in the electricity and heat supply sectors. Growth has also been observed in India and South Korea due to sustained economic growth. However, Japan's consumption has declined since restarting nuclear reactors has reduced the need for gas-fired electricity production.

Gas consumption also continued to grow steadily in Russia (albeit at a slower pace than in 2017) and accelerated in Canada, Iran and Algeria.

Despite economic growth, gas consumption in Europe, especially in Turkey, France, Germany and Italy, declined due to rising temperatures, increased availability of nuclear and hydropower, as well as increased production of renewable energy (Figure 2).

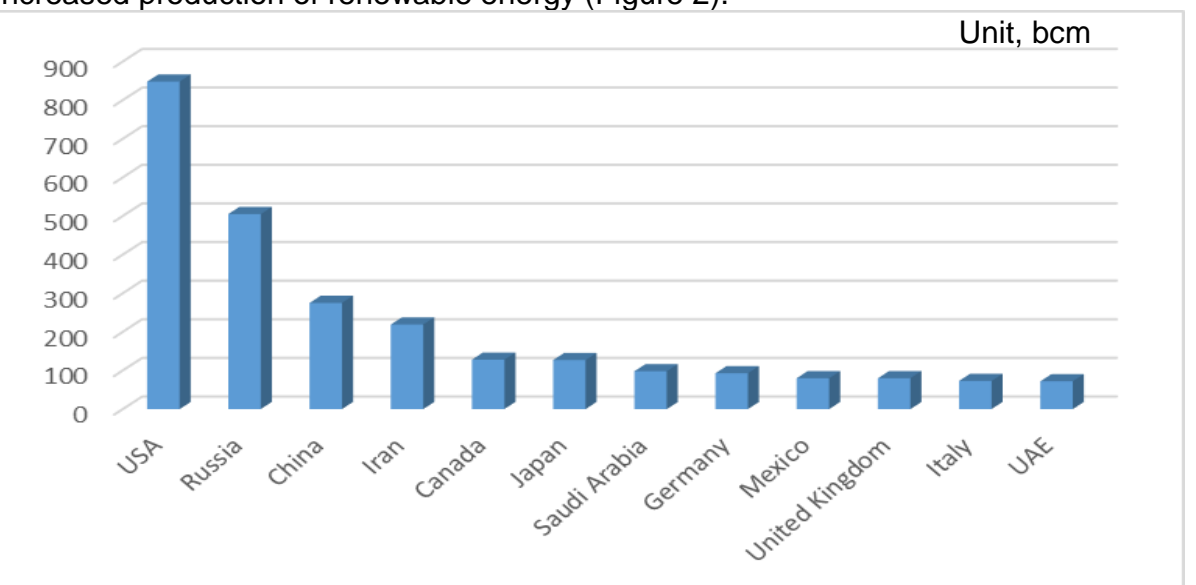

Figure 2.

Source: own development based on the data (Statistical Yearbook of World Energy, 2019)

Coal, lignite. World coal production increased $(+1.9 \%)$ for the second year in a row China has strengthened its position as the world's largest producer of coal and brown coal $(45 \%$ of world production). In 2018, the country approved more than 45 billion Chinese yuan ( $\$ 6.7$ billion) for new 
coal mining projects. The recent gas shortage in the country has weakened the government's motivation to switch from coal to gas used for space heating and has retained its appetite for coal. Coal and brown coal production in China accounted for $70 \%$ of global growth. The increase in coal imports to China (by $4 \%$ compared with 2018 , the highest growth over the past four years) supported a strong international coal market, boosting production in Australia, Indonesia and Russia, the three main suppliers of coal. In India, there was a significant increase in production (+ $5.3 \%$ in 2018$)$, due to domestic demand and the government's ambitions to reduce dependence on imports. Coal production in the United States fell its lowest level in 39 years, despite rising exports. Coal mining also continued to decline in the European Union, as member states are increasingly committing themselves to rid the economy of coal.

Oil, gas and coal until the end of the XXI century. Will remain the basic elements of energy, their share will be about half of the global energy balance. The rational use of non-renewable resources is the most important task of the world community. Currently, oil, gas and coal are used primarily as fuel, and only $4-5 \%$ of their volume is supplied to the chemical industry. In the future, a multiple increase in the production of non-fuel products (synthetic materials, fertilizers, etc.) will be required. Oil and gas will retain their leading positions not only as sources of energy, but also as the most important raw material for obtaining special materials necessary for the development of modern civilization. According to forecasts, by the middle of the XXI century. In the chemical industry, up to $10 \%$ of hydrocarbons produced will be used, and by the end of the century - up to $30 \%$. These volumes should be excluded from the global fuel and energy complex (the load on other energy sectors will increase accordingly) (Figure 3).

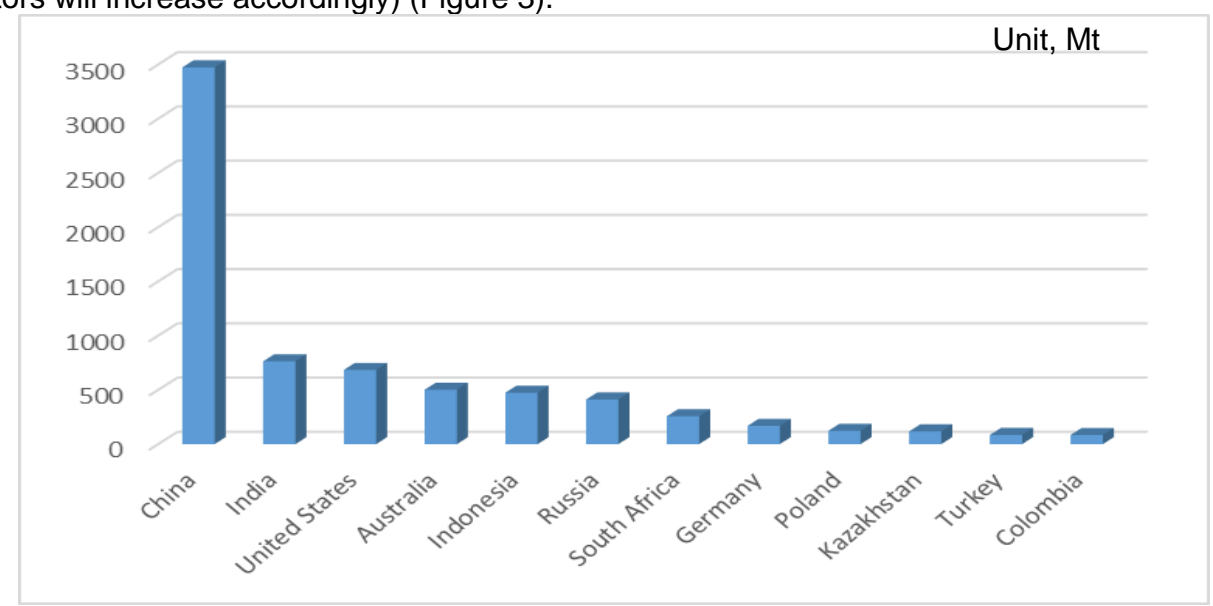

Figure 3.

Source: own development based on the data (Statistical Yearbook of World Energy, 2019)

Economics of nuclear energy. Investments in nuclear energy, like investments in other areas of electricity production, are economically justified if two conditions are met: the cost of a kilowatt hour is not more than with the cheapest alternative production method, and the expected demand for electricity is high enough so that the generated energy can be sold At a price in excess of its cost. In the early 1970s, world economic prospects looked very favorable for nuclear power: both the demand for electricity and the prices of the main types of fuel - coal and oil - were growing rapidly. As for the cost of building a nuclear power plant, almost all experts were convinced that it would be stable or even begin to decline. However, in the early 1980s, it became clear that these estimates were wrong: the growth in demand for electricity stopped, the price of fossil fuels not only did not increase anymore, but even began to decline, and the construction of nuclear power plants was much more expensive than anticipated in the most pessimistic forecast. As a result, nuclear energy everywhere entered a period of serious economic difficulties, the most serious in the country where it arose and developed most intensively - in the United States.

If you conduct a comparative analysis of the economy of nuclear energy in the United States, it becomes clear why this industry has lost competitiveness. Since the early 1970s, the cost of a 
nuclear power plant has risen sharply. The cost of a conventional thermal power plant consists of direct and indirect investments, fuel costs, operating costs and maintenance costs. Over the life of a coal-fired power plant, fuel costs average $50-60 \%$ of total costs. In the case of a nuclear power plant, investments dominate, accounting for about $70 \%$ of all costs. Capital expenditures for new nuclear reactors on average significantly exceed the costs of fuel from a coal-fired power plant over their entire service life, which negates the advantage of fuel savings in the case of a nuclear power plant.

Prospects for nuclear power. Among those who insist on the need to continue the search for safe and economical ways to develop nuclear energy, two main directions can be distinguished. Supporters of the first believe that all efforts should be focused on eliminating public distrust in the safety of nuclear technology. To do this, it is necessary to develop new reactors that are safer than existing light-water ones. Two types of reactors are of interest here: a "technologically extremely safe" reactor and a "modular" high-temperature gas-cooled reactor.

A prototype modular gas-cooled reactor was developed in Germany, as well as in the USA and Japan. Unlike a light-water reactor, the design of a modular gas-cooled reactor is such that the safety of its operation is ensured passively - without direct actions by operators or an electrical or mechanical protection system. In technologically extremely safe reactors, a passive protection system is also used. Such a reactor, the idea of which was proposed in Sweden, apparently did not advance beyond the design stage. But he received serious support in the United States among those who see his potential advantages over a modular gas-cooled reactor. But the future of both options is vague due to their uncertain cost, development difficulties, as well as the controversial future of nuclear energy itself.

At nuclear power plants (NPPs), about $16 \%$ of the world's electricity is generated, and for many developed countries their share exceeds $60-70 \%$. Currently, nuclear power plants have been built in 32 countries, with about $70 \%$ of the world's electricity production coming from 5 of them (USA, France, Japan, Germany and Russia). A world nuclear program is being formed that provides uniform safety standards and provides for controlled access of developing countries to peaceful nuclear technologies. The international cooperation of the leading countries in world energy is expanding. In the XXI century. The structure of nuclear energy will change. Fast neutron reactors will be developed and in the future thermonuclear fusion, the introduction of which will not only greatly increase the capacity of the nuclear industry, but also make it as safe as possible. In addition, the use of breeder reactors increases the efficiency of the use of uranium ore by 60 times, which will provide nuclear energy with resources for at least a thousand years.

Modern technologies ensure reliable disposal of radioactive waste, and the transition to a closed nuclear cycle will allow for their processing and reuse in new generation reactors. As a result of large-scale international events on the safety of nuclear power plants and waste disposal, public confidence in nuclear energy has increased. In most countries, multiple growth of the nuclear industry is planned (Figure 4).

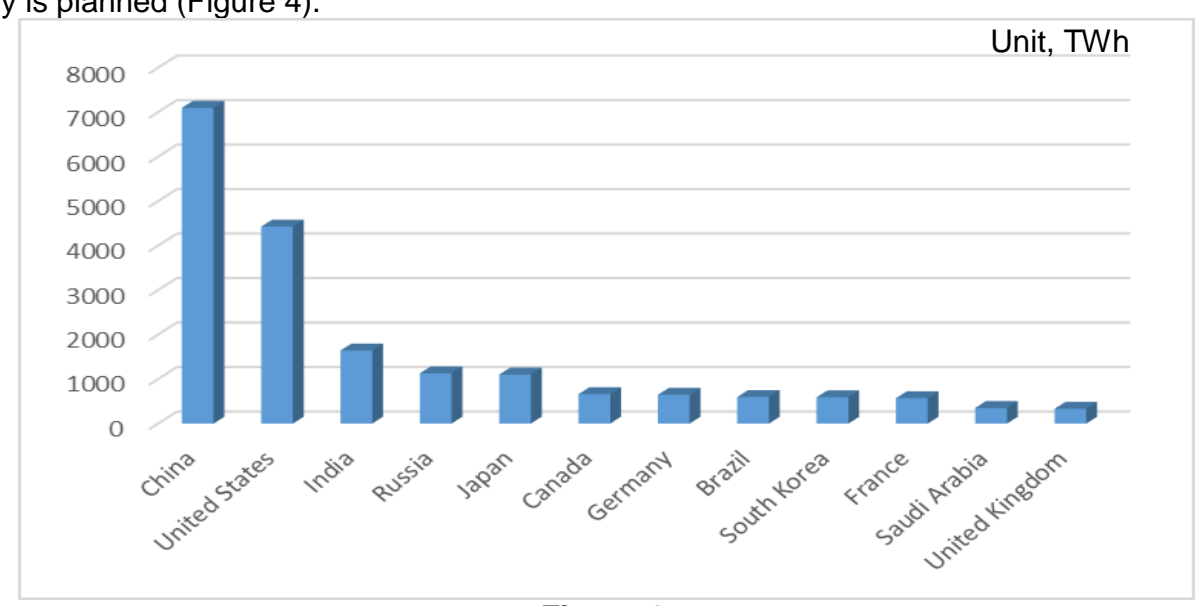

Figure 4.

Source: own development based on the data (Statistical Yearbook of World Energy, 2019) 
China and the United States accounted for three-quarters of the growth in global electricity production in 2018. The main increase in global electricity production in 2018 occurred in Asia (+ $6.1 \%$ ): China accounted for almost $60 \%$ of global growth thanks to strong demand and the rapid development of generating capacities, followed by India, Japan, South Korea and Indonesia.

Electricity generation also increased in the United States $(+3.6 \%)$, as weather conditions and economic growth stimulated electricity consumption, while in Canada it decreased slightly. Electricity production continued to grow in Russia (economic recovery), the Middle East and Africa. In Latin America, it remained stable as growth in Brazil and Mexico was offset by a strong recession in Venezuela caused by political tensions.

In Europe, electricity production remained stable despite growth in France and Turkey due to increased production of hydropower and renewable energy (plus improved nuclear availability in France). On the other hand, electricity production declined in Belgium (significant inaccessibility of atomic energy), Germany, Italy and the United Kingdom (mild winter).

Use of fuel and energy resources and renewable energy sources as a possible way to increase resource efficiency

Renewable energy is defined as an inexhaustible and rapidly renewable source of energy. Renewable energy is obtained through the use of ordinary natural phenomena, such as wind, hydropower, plant energy, or the energy of other planets, such as sunlight or radiated from the Earth's core (geothermal energy).

Solar power. This energy is the production of heat by converting the energy inherent in sunlight. This energy attracts the heat of the sun and its photovoltaic cells and transfers it to the water cycle to supply houses with hot water or heating. There are several methods for the efficient use of solar energy, which can be divided into three main categories: thermal applications, electricity production and chemical processes, and the most widely used areas of application are water heating. Electricity is now increasingly being generated by photovoltaic systems and solar thermal technology, as the focus is on converting sunlight into electricity using solar panels. The advantages of photovoltaic cells lie in their ability to convert solar energy directly into electricity and in its ease of use, which makes them suitable for use, especially in developing countries where there are no large generators. It should be noted that the output of these cells remains limited, since the amount of energy received depends on the geographical location and is associated with climatic conditions, and the period of use is no more than twenty years. This means that the energy of fossil fuels (such as oil and coal) can be replaced, but there is a problem of their storage, since this energy cannot be stored for years. On the other hand, it can be used to produce $50 \%$ of the energy needed for heating. The cost of solar thermal energy is still relatively high due to the high investment cost necessary for its construction, which can only be restored after a relatively long period, which can last from 10 to 15 years.

In this context, the Greenpeace report of October 7, 2005, entitled Concentrated Solar Thermal Energy, stated that by 2025 , solar energy would provide clean electricity for two decades to more than 100 million people in areas of the sun most exposed to the sun. . Greenpeace encourages decision makers to support this modern, sustainable industry and invest in this new technology. The report also shows how the Middle East and North Africa can become the main center of solar energy production in the world and be able to export this energy to Europe.

Solar energy has proven its technical and economic sufficiency in the field of heating water and generating electricity using solar cells, and solar energy from other energy sources is of excellent quality in reducing fuel consumption and environmental pollution. Solar energy is almost free, but requires large costs for the production and conversion of energy-generating devices. Modern research aims to reduce these costs to a minimum. Today it has become possible to design solar power plants with a capacity of 80 hybrid megawatts, which operate on solar energy during the day and natural gas at night, thereby reducing the cost per kilowatt hour is very high. However, prices for solar energy do not obey the well-known law of supply and demand, but depend on the law of economies of scale.

Wind energy. A 2006 World Wind Energy Association (WWEA) report indicated that wind energy technology is the most dynamic source of energy and the most promising alternative to fossil fuel production. Wind power is considered one of the most important sources of renewable energy. The cost of wind energy has become competitive compared to traditional energy, since the cost of producing a kilowatt of wind energy has reached $\$ 1,000$, while the cost of $\mathrm{kW}$ of production from 
conventional energy is up to $\$ 800$. Currently, wind energy generates more than $1 \%$ of global electricity consumption.

The cost of electrical energy generated by wind energy has become very low. The use of intelligent electronic controls, the use of streamlined surfaces and the continuous improvement of the materials used in the production of wind energy have provided additional benefits in providing such ener Biomass energy

Biomass energy. Biomass is already the leading source of renewable energy in Europe, but it has not yet fully revealed its potential, because even when produced and consumed locally, it is an important component of the circular economy in the field of energy. As a substitute for fossil fuels, it significantly reduces $\mathrm{CO} 2$ emissions and protects users from price fluctuations that are characteristic of oil and gas markets. Recycling wood waste is also a potential source of fuel, and prudent reforestation also contributes to $\mathrm{CO} 2$ capture.

Many economists point out that biofuels are a green alternative to oil, and there are two main brands on the world market - biodiesel and ethanol, which are usually produced from food crops. Ethanol is extracted from sugarcane, corn, wheat and other grains containing sugar or starch and is added to gasoline, and it makes up more than $90 \%$ of the total biofuel production in the world.

Options for solar energy provide an implicit accumulation of green matter in biomass, which is formed as a result of photosynthesis, and store part of the solar energy in the form of chemical energy, which can be restored by burning the plant.

Unlike fossil fuels, biomass has several advantages, as it is available in most parts of the Earth and contains less than 0.1 percent sulfur and 3 to 5 percent ash and is equivalent to the amount of carbon dioxide released from biomass during combustion. This means that bioenergy does not emit any additional carbon dioxide into the atmosphere.

Biomass is widely used to generate electricity and heat in the forest industry. The remaining wood waste obtained during the production process uses fuel for cogeneration systems operating on turbine turbines. This method is economical only in areas where cheap biomass fuel is widely available.

One of the striking examples of the efficient use of materials and energy in industry is Finland.

Finland's pulp and paper industry is a prime example of a large industry where almost all materials and by-products from wood processing are already used to produce many types of products or to generate renewable energy. Finnish firms are quickly finding new uses for innovative wood biomaterials, thereby improving the use of biomass from the rationally managed forests of Finland, where more wood is harvested each year than harvested.

Improving the process of using raw materials, as a rule, goes hand in hand with energy savings. As a cold climate country that does not have its own fossil fuel reserves, Finland has long recognized the need for energy efficiency in industry and residential buildings. Given the need to reduce emissions and reduce global warming, the dissemination of such experiences is now more important than ever.

In addition to building sustainable carbon-neutral bioeconomics by rationalizing the use of forest biomass, Finland is also actively introducing the concept of a circular economy in other key areas.

Finnish forest machine manufacturers Ponsse were the first to adopt the modular product concept by starting to assemble machines from multi-purpose parts that can be easily removed and sent for maintenance and reuse, even if only through their international sales network.

Geothermal energy. Geothermal energy depends on the use of energy contained in the soil for heating or converting it into electricity. To produce energy from the bowels of the earth, water is heated underground, and then uses its thermal energy to generate electricity. The most important part of the energy hiding on Earth is related to the radioactivity of the rocks that make up the earth's crust. This can be described as a type of natural nuclear energy that comes from the decomposition of uranium, thorium and potassium. This energy is not related to climate change, and the duration of the geothermal mines is estimated at tens of years. A 2007 report by the International Geothermal Association indicates that the world's geothermal energy has reached 7.9 gig watts, an increase of 800 megawatts than in 2005 . This clean energy is used by most countries in the world to combat environmental pollution, and the total energy capacity is distributed. Geothermal in different proportions for producing countries.

Similarly, the 2009 GEO report indicated that the Australian government announced a \$43 million project to help extract energy from the heat of the earth, being the world's largest coal 
exporter, which generated about $77 \%$ of its electricity. This makes it the world's largest source of population pollution.

The report added that only $1 \%$ of geothermal energy in Australia can meet the need for clean electricity for 26,000 years. This technology, sometimes called "hot stones," has enormous potential for Australia, on the other hand, as a way to counter climate change and national energy security, and that the first installations of this energy can start operating in 2012. Switzerland is also a world leader in the exploitation of geothermal energy. It has the highest percentage of underground energy facilities, since the number of institutions based on investments of the interior of the Earth (both wind and water) has reached 50,000 installations, but it lacks stations that convert this energy into electrical energy, unlike That was found in Germany And even in Italy, which, thanks to the underground power station in Tuscany, managed to become the first producer of this type of electricity (Kalogirou, 2009).

Hydropower. Hydroelectric power plants produce electricity using the power of (falling) water, which drives the so-called turbine, which in turn rotates the metal axis connected to the generator. The principle is to build a river water dam to store large amounts of water and to obtain great heights, and thus the water is taken through pipes from the bottom of the dam wall, where the water pressure is proportional to the height of the dam water to reach the turbine blades and make it rotate that, In turn, connected with the axis of the generator. And when the magnetic poles rotate in the generator, alternating electric current will be generated in the windings. The height of the water in the tank is stored in energy. When the dam opens, the water passing through the turbine turns into kinetic energy. The amount of generated electricity is determined by several factors, two of which are the volume of running water and the height of the dam surface from the turbine (engine). As well as the height and flow of water increases, electrical energy is generated. This energy is related to the amount of stored water.

Alternative energy has come to the fore in the energy sector of Belarus. In the Republic of Belarus, more than twenty thousand small rivers flow, the length of which is 90 thousand kilometers. Small hydroelectric power plants have been built in the country. Osipovichi Hydroelectric Power Station was first built in 1954 on the Svisloch River. Its capacity was only $2.25 \mathrm{MW}$., Which is still in effect to this day.

However, by the 60s, the small hydroelectric power station had gone aside due to the emergence of state power systems. Consumers in rural areas were transferred to a powerful new system, and the need for small hydropower plants disappeared on its own. As a result, by the end of the 80 s in Belarus there were only six hydroelectric power plants, which produce more than 18 million kilowatts annually.

Over time, energy was converted by a small hydropower plant (SHP). In this case, alternative sources of energy in Belarus as it turned out to be possible to acquire, restore. Representatives of the Greens confirm that small hydropower plants have no environmental burden.

The Belarusian authorities planned to double the total capacity of hydroelectric power plants. In this regard, a certain interest in the construction of small hydropower plants in the country is shown by foreign investors, who take $78.4 \%$ for the construction of small energy costs.

A hydroelectric power station for generating electricity provides an important part of the demand for electricity in Lebanon. In connection with this, several projects for water supply on the river and sources appeared, covering 16 factories with a total capacity of 283,146 megawatts, in particular three Litani plants with a total capacity of 191,500 megawatts, accounting for $67.6 \%$ of production. The annual production volume (more than 20 years) reached $722 \mathrm{MW} /$ hour, which accounts for Litani factories, of which about $500 \mathrm{MW} /$ hour. Experts note that the capacity of the hydraulic unit in Lebanon is estimated at 284 megawatts, and its current production is less than 48 megawatts.

In light of the growing shortage of electricity generation and unprecedented losses, as well as an increase in demand for consumption (current demand of no less than 3,000 megawatts compared to actual production of about 1,400 megawatts), as well as the need to preserve the environment, attention was directed to Renewable energy, the most important of which is hydropower, on the availability of potential water energy in Lebanon and its economic water projects (Белорусская Атомная Электростанция).

The Ministry of Energy and Water Resources is currently working on the search for the best technical, financial and political solutions to reduce the budget deficit as soon as possible in a way that is consistent and integrated with the electricity policy document approved by the Cabinet of 
Ministers in its decision No.1, which formed a common framework for the sector. Electricity in Lebanon is parallel, and to facilitate the receipt of the promised funds for the energy sector from the CEDRE conference, the Ministry of Energy and Water collaborated during 2018 with the World Bank to prepare assessment studies of the energy sector in Lebanon, where it issued a series of recommendations after scheduling decisions (AES Ironwood CCGT Power Plant).

The share of wind and solar energy is growing rapidly and steadily (0.8 points in 2018), reaching $7.5 \%$ of the energy balance. In 2018 , the share of wind and solar energy in the global energy balance increased by 0.8 points, since in 2018 it accounted for more than $30 \%$ of the total additional electricity generation (16\% for solar energy and $15 \%$ for wind). In 2018 , the share of wind and solar energy in all regions, especially in Latin America (large-scale introduction of renewable energy sources in Brazil and Chile), Asia (China, India and Japan) and Europe (especially in Germany, Great Britain, Belgium and Turkey), Continued to grow, driven by lower technology costs and ambitious policies. Wind and solar technology is also gaining momentum in the United States and Australia. They still remain negligible in Africa and in fossil fuel extraction areas (CIS and Middle East) (Figure 5).

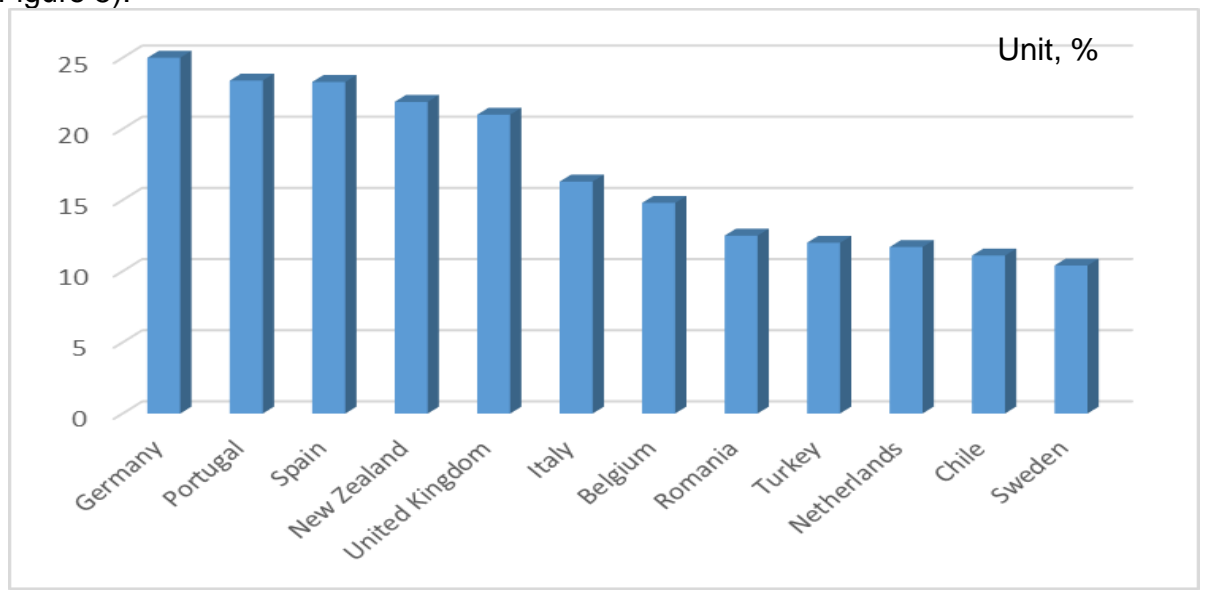

Figure 5.

Source: own development based on the data (Statistical Yearbook of World Energy, 2019)

Ways to Improve Energy Efficiency. Currently, there is growing interest and competition for serious investments in the development of alternative energy programs and technologies, as well as the introduction and use of green technologies in several areas, which together will determine the future energy in the world.

Economic energy, in an economic concept, is an expression intended for energy production, investment, consumption and the benefits arising from this, and includes all means and procedures aimed at increasing the return on energy use and reducing its losses to a minimum, without affecting Economic growth, that is, the consumption of the least.

Likewise, energy conservation aims to extract as much energy as possible from its primary sources, while preserving the environment and minimizing its harm.

The circular economy provides pragmatic and effective solutions for the gradual depletion of vital resources for the functioning of the modern economy. Closing the cycles of materials, water and energy, this "other" economy allows the economy to grow, while reducing extraction from nature.

The circular economy multiplies the productivity of resources produced by nature in terms of resource efficiency. It is aimed not only at the optimal use of water and raw materials, but also at energy resources.

The potential for reducing fossil fuel consumption through energy efficiency policies is much greater than replacing these fossil energy sources with other renewable energy sources.

High energy consumption in the processing industries raises a number of serious environmental problems. Lack of equipment and a lag in technology led to a significant excess of total emissions. The amount of total annual emissions of industrial pollutants is increasing. Pollution of air, water and 
solid waste is a serious threat to human health and environmental safety. The technical bottlenecks and environmental problems of the processing industries severely impede sustainable development. With economic development, population growth and improving living standards, the amount of energy consumed will undoubtedly increase in the future. Therefore, improving energy efficiency is vital to energy conservation efforts in the manufacturing industry. There is tremendous potential for energy savings in the manufacturing industry. Energy-saving technologies - technical updating, elimination of obsolete equipment, new production facilities using advanced technologies.

Positive effects of green and circular economies. The circular economy is one of the directions of the green economy, offering the state and business modern approaches to improving resource efficiency, achieving a social effect in the sphere of consumption of goods, in particular, due to the expanded responsibility of the manufacturer, as well as reducing the environmental footprint of production and manufactured goods. The concept of a circular economy is the practical basis for the implementation of the green economy and offers effective business models to ensure more environmentally friendly resource use, contributing to the achievement of the goals of sustainable development of society (Yaryhina, 2019).

Some economists argue that policies that do not address environmental issues such as resource depletion, biodiversity loss, increasingly intense storms and floods and droughts due to climate change can lead to job losses and livelihoods. Therefore, solving environmental problems opens up opportunities for workers and employers and reflects economic growth. Thus, today's climate change industry will be at the forefront of the CleanTech sector. Global efforts to combat climate change and its effects have changed employment and investment patterns in the green economy. A large number of jobs and millions of green jobs were created in sectors such as renewable energy, energy efficiency of buildings, sustainable transport systems, agriculture, environmental protection, industry, research and development, management, activities and services. Green jobs are jobs that help mitigate the environmental threats facing humanity. Thus, the Clean Development Mechanism and the joint implementation tools included in the Kyoto Protocol, according to which companies and governments can receive carbon credits by supporting specific emission reduction projects, are potential financing mechanisms for green projects.

The ability of the environment to absorb contaminated waste. The ability of the environment to absorb contaminated waste and other impacts of energy technology is limited. This is manifested in two main classes of environmental costs: "external" costs, which are imposed by society's corruption on society and do not affect the financial accounts of consumers and energy producers, and "input costs", which represent an increase in financial costs caused by measures aimed at To reduce external costs.

Both types of environmental costs have been and are increasing for many reasons, including: reduced quality in fuel production basins and energy transmission sites, the need to transport more materials over long distances and the construction of larger facilities, as well as the growing volume of contaminated waste from energy systems and the need to meet The ability of the environment to absorb waste. Such waste is not contaminated, and pollution control costs tend to increase with increasing pollution. The combination of increased energy consumption with a decrease in the quality of resources requires the removal of an increasing percentage of pollutants in order to maintain the level of damage unchanged. And this means an increase in input costs, in addition to the fact that public and political interest in the environment extends the time for choosing licensing and construction of energy facilities, and also increases the frequency of changes to project specifications before implementation and guidelines, which leads to another increase Costs.

Waste recovery underlies the concept of a circular economy. This should be one of the main pillars of the industrial renaissance in the EU. The waste sector can and should contribute to improving the efficiency of resource use in the economy, provided that appropriate policies are applied. This is consistent with the leading EU initiative for a resource-efficient Europe, which was launched in 2011 as part of the Europe 2020 Strategy. The initiative supports the transition to a resource-saving low-carbon economy to achieve sustainable growth ("Circular economy and», 2014).

Energy of the future. Assuming that by 2100 the vast majority of the world's population should be provided with energy at a level corresponding to today's consumption in developed countries, the full satisfaction of humanity's energy needs in 2100 with a population of 11.213 billion will amount to 55.98 billion toe / Year $(2.34 \times 1021 \mathrm{~J} /$ year $)$. 
With an average energy production efficiency of $68 \%$ in $2100,81.68$ billion toe / year $(3.42 \times$ $1021 \mathrm{~J}$ / year) should be produced, or 4.2 times more than in 2015.

All this energy, in accordance with physical laws, will become thermal waste and their accumulation will inevitably lead to catastrophic global warming, which can reach $5.5-7^{\circ} \mathrm{C}$ by 2100 , rise in ocean level by 6-9 m, disappearance of glaciers - sources of drinking water For many regions.

To date, there are no sources capable of providing even part of the energy production required by 2100 , especially with the upcoming exhaustion of hydrocarbons.

The only source of energy that is able to provide the future of mankind is the Sun, which in 1 hour gives energy to the Earth in the volume of consumption of all mankind in 2015.

However, the problem is that the density of solar energy at the equator does not exceed $360 \mathrm{~W}$ / m2 and solar panels with an area of about 10 million km2, taking into account the areas for maintenance and a 4-hour duty cycle, will be required to provide humanity with energy.

For comparison, the total area of the EU countries is 4.3 million km2, Kazakhstan - 2.72 million $\mathrm{km} 2$, the United States - 9.5 million $\mathrm{km} 2$.

In addition, about 200 million tons of today's most advanced batteries will be needed, with an annual replacement of 30 million tons.

Other energy sources also do not have a long-term global perspective: hydropower - the potential is almost exhausted, wind - low power density, uncontrolled frequency.

Nuclear and thermonuclear energy, according to the models of individual organizations, are able to provide the world's energy needs of mankind for many centuries, but this will inevitably lead to environmental problems and an increase in the rate of global warming (Школьник, Канимов, \& Канимова, 2019).

In the XXI century. Oil, gas and coal will remain the main sources of global energy. The high efficiency of these energy sources is of great importance for the sustainable development of mankind. At the same time, the global energy development strategy should take into account the prospects for using environmentally friendly energy sources and the latest technologies for their development, which will guarantee the energy security of our civilization. The world community must make a grandiose scientific and technological breakthrough in the development of the energy of the earth's interior, the ocean, the sun, space and the peaceful atom. Only then can we satisfy the growing demand for clean, plentiful, reliable and safe energy - the basis of a high standard of living, a developed economy and culture, international and national security. We must multiply this source of vitality and transfer it to the reliable hands of our descendants.

Conclusion. "The energy sector, which for decades has contributed to the growth and prosperity of the global economy, has contributed to increased emissions and is therefore responsible for reducing them," says Eni CEO Claudio Descalzi. (https://www.eni.com/en-IT/circulareconomy/sustainable-world.html Mike Scott), This means that we all need to use energy more efficiently in order to be able to separate economic growth from use Resources and greenhouse gas emissions. One of the best ways to do this is to apply the principles of a circular economy to energy production and consumption. The circular economy provides pragmatic and effective solutions for the gradual depletion of vital resources for the functioning of the modern economy. Closing the cycles of materials, water and energy, this "other" economy allows the economy to grow, while reducing extraction from nature.

The concept of a circular economy is the practical basis for the implementation of the green economy and offers effective business models to ensure more environmentally friendly resource use, contributing to the achievement of sustainable development goals of society.

In fact, economic security can mean creating new jobs or searching for product markets. The idea of national security is that lower energy demand will affect our sense of global security. An analysis of many studies shows that the potential of the Earth's natural resources can provide humanity with energy for the long term. But an analysis of other studies also shows that in the future we can expect that oil production will peak and consumption and prices will continue to grow, disputes and conflicts over limited resources will increase and become constant. The energy sector in all countries plays a vital role in socially And economic development Oil, gas and coal until the end of the 21st century. Will remain the basic elements of energy, their share will be about half of the global energy balance. The rational use of non-renewable resources is the most important task of the world community. 
Investments in nuclear energy, like investments in other areas of electricity production, are economically justified if two conditions are met: the cost of a kilowatt hour is not more than with the cheapest alternative production method, and the expected demand for electricity is high enough so that the generated energy can sell.

Renewable energy is defined as an inexhaustible and rapidly renewable source of energy. Renewable energy is obtained through the use of ordinary natural phenomena, such as wind, hydropower, plant energy, or the energy of other planets, such as sunlight or radiated from the Earth's core (geothermal energy).

The ability of the environment to absorb contaminated waste and other impacts of energy technology is limited. This is manifested in two main classes of environmental costs: "external" costs, which are imposed by society's corruption on society and do not affect the financial accounts of consumers and energy producers, and "input costs", which represent an increase in financial costs caused by measures aimed at To reduce external costs.

The only source of energy that is able to provide the future of mankind is the Sun, which in 1 hour gives energy to the Earth in the volume of consumption of all mankind in 2015.

\section{Література}

1. Энергетическая безопасность. Термины и определения / Отв. редактор чл.-корр. РАН Воропай Н.И. М.: ИАЦ Энергия, 2005. 60 с.

2. Макаров А.А. Мировая энергетика и Евразийское энергетическое пространство. М.: Энергоатомиздат, 1998. 280 с.

3. Popescu M.-F. (2015). The Economics and Finance of Energy Security. Procedia Economics and Finance. 2015. Vol. 27. P. 467-473. DOI: https://doi.org/10.1016/S2212-5671(15)01022-9.

4. Мазур И.И. Глобальная энергетическая безопасность. Век глобализации. 2008. №1. С.57-69. URL: https://www.socionauki.ru/journal/articles/129825/.

5. Circular Economy Action Plan. The EU Switch to green Flagship Initiative, EU Best Practise. URL: https://www.switchtogreen.eu//wordpress/wp-content/uploads/wp-post-to-pdf-enhanced-cache/1/circulareconomy-strategy.pdf.

6. Circular economy and resource efficiency: a driver of economic growth in Europe. 2014. European Issue $n^{\circ} 331$. URL: https://www.robert-schuman.eu/en/european-issues/0331-circular-economy-and-resourceefficiency-a-driver-of-economic-growth-in-europe\#ancre 1.

7. Statistical Yearbook of World Energy. 2019. URL: https://yearbook.enerdata.ru/crude-oil/worldproduction-statitistics.html.

8. Kalogirou S. Solar energy engineering: processes and systems (1st Edition)/ USA: Academic Press Elsevier Inc. 2009. 778 p.

9. Республиканское Унитарное Предприятие «Белорусская Атомная Электростанция». URL: http://belaes.by/ru.

10. AES Ironwood CCGT Power Plant, Lebanon, PA. URL: https://www.power-technology.com/projects/aes/.

11. Yaryhina $\mathrm{H}$. Analysis of the concepts of sustainable development of green and circular economies. Proceedings of young specialists of Polotsk State University “Economic Sciences". 2019. No. 26 (96). P. 82-85.

12. Школьник В., Канимов Б., Канимова Э. Всемирная энергетическая система. 2019. URL: http://www.atominfo.ru/newsz/a0790.htm.

\section{References}

1. Voropay, N.I. (Ed.). (2005). Energy security. Terms and definitions. Moscow: IAC Energy. (in Russian)

2. Makarov, A.A. (1998). World energy and the Eurasian energy space. Moscow: Energoatomizdat. (in Russian)

3. Popescu M.-F. (2015). The Economics and Finance of Energy Security. Procedia Economics and Finance, 27, 467-473. doi: https://doi.org/10.1016/S2212-5671(15)01022-9.

4. Mazur, I.I. (2008). Global energy security. The Age of Globalization, 1, 57-69. Retrieved from https://www.socionauki.ru/journal/articles/129825/. (in Russian)

5. Circular Economy Action Plan. The EU Switch to green Flagship Initiative, EU Best Practise. Retrieved from https://www.switchtogreen.eu//wordpress/wp-content/uploads/wp-post-to-pdf-enhanced-cache/1/circulareconomy-strategy.pdf. 
6. Circular economy and resource efficiency: a driver of economic growth in Europe. (2014). European Issue $n^{\circ} 331$. Retrieved from https://www.robert-schuman.eu/en/european-issues/0331-circular-economy-andresource-efficiency-a-driver-of-economic-growth-in-europe\#ancre 1.

7. Statistical Yearbook of World Energy. (2019). Retrieved from https://yearbook.enerdata.ru/crudeoil/world-production-statitistics.html.

8. Kalogirou, S. (2009). Solar energy engineering: processes and systems (1st Edition)/ USA: Academic Press (Elsevier Inc.)

9. Republican Unitary Enterprise «Belarusian Atomic Power Plant». Retrieved from http://belaes.by/ru/.

10. AES Ironwood CCGT Power Plant, Lebanon, PA. Retrieved from https://www.power-technology.com/projects/aes/.

11. Yaryhina, H. (2019). Analysis of the concepts of sustainable development of green and circular economies. Proceedings of young specialists of Polotsk State University "Economic Sciences", 26(96), 82-85.

12. Shkolnik, V., Kanimov, B., Kanimova, E. (2019). World energy system. Retrieved from http://www.atominfo.ru/newsz/a0790.htm. (in Russian)

\section{І.В. Зенькова}

кандидат економічних наук, доцент

Полоцький державний університет вул. Блохіна, 29, м. Новополоцьк, Вітебська обл., 211440, Республіка Білорусь E-mail: i.zenkova@psu.by, ORCID: https://orcid.org/0000-0002-6978-5446

Г.М. Яригіна асистент, аспірант

Полоцький державний університет вул. Блохіна, 29, м. Новополоцьк, Вітебська обл., 211440, Республіка Білорусь E-mail: g.yarygina@psu.by

Рабіх Саїд Саті

аспірант

Полоцький державний університет вул. Блохіна, 29, м. Новополоцьк, Вітебська обл., 211440, Республіка Білорусь E-mail: rabih.sati67@gmail.com

\section{ГЛОБАЛЬНА ЕНЕРГЕТИЧНА БЕЗПЕКА ТА МІЖНАРОДНИЙ ЕКОНОМІЧНИЙ РОЗВИТОК}

Питання енергетичної безпеки - одні з найважливіших в міжнародному політичному та економічному порядку денному в силу їх важливості для економічного і соціального розвитку окремих країн, відносин між ними, а також для світової економіки та навколишнього середовища. Дійсно, важко уявити область, в якій країни є більш взаємозалежними, ніж в сфері злиття енергетики, навколишнього середовища та економічного розвитку. Енергетична безпека має значення для внутрішньої і зовнішньої політики. Це означає взаємозалежність між виробником і споживачем, де взаємна уразливість і взаємна вигода $є$ і короткостроковими, і довгостроковими. У статті систематизовано види енергії з метою сталого розвитку: баланс економічної, соціальної та екологічної складових за допомогою моделі економіки замкнутого циклу, яка дозволяє досягти енергетичної безпеки. Першим кроком є перехід від вуглецевої енергії (нафта, газ, вугілля) до чистої енергії (сонячна енергія, енергія вітру, гідроенергетика тощо). Однак, не менш важливо дотримуватися принципу енергоефективності, який полягає в порівняння різниці між фрактично використаною енергією і загальною спожитою енергією (часто більш високою через втрати). Принципи циркулярної економіки, спрямовані на досягнення найбільш ефективного використання ресурсів, $€$ найважливішими при розробці інноваційних рішень, спрямованих на перехід до чистої енергії. Вивчивши різні підходи шляхом порівняння і аналогії, ми можемо зробити висновок, що Концепція економіки замкнутого циклу пропонує ефективні бізнес-моделі для забезпечення екологічно безпечного використання ресурсів, сприяючи досягненню цілей товариства в сфері сталого розвитку. У статті використані історичні та статистичні методи, а також системний підхід до вивчення економічних явищ, який дозволив виявити взаємозв'язок між усіма елементами і їх роллю в загальному функціонуванні економіки замкнутого циклу. Використовуючи метод порівняння і наукове моделювання, розкривається роль економіки замкнутого циклу в ресурсозбереження, мінімізації відходів і зниження навантаження на навколишнє середовище при досягненні значних економічних і соціальних результатів в області енергетичної безпеки.

Ключові слова: енергетична безпека, економіка замкнутого циклу, ресурси, енергія, екологія.

JEL Classification: P48, Q43, Q56, Q57. 
И.В. Зенькова

кандидат экономических наук, доцент Полоцкий государственный университет ул. Блохина, 29, г. Новополоцк, Витебская обл., 211440, Республика Беларусь E-mail: i.zenkova@psu.by, ORCID: https://orcid.org/0000-0002-6978-5446

Г.Н. Ярыгина

асистент, аспирант

Полоцкий государственный университет ул. Блохина, 29, г. Новополоцк, Витебская обл., 211440, Республика Беларусь E-mail: g.yarygina@psu.by

Рабих Саид Сати аспирант

Полоцкий государственный университет ул. Блохина, 29, г. Новополоцк, Витебская обл., 211440, Республика Беларусь E-mail: rabih.sati67@gmail.com

\section{ГЛОБАЛЬНАЯ ЭНЕРГЕТИЧЕСКАЯ БЕЗОПАСНОСТЬ И МЕЖДУНАРОДНОЕ ЭКОНОМИЧЕСКОЕ РАЗВИТИЕ}

Вопросы энергетической безопасности - одни из важнейших в международной политической и экономической повестке дня в силу их важности для экономического и социального развития отдельных стран, отношений между ними, а также для мировой экономики и окружающей среды. Действительно, трудно представить область, в которой страны являются более взаимозависимыми, чем в сфере слияния энергетики, окружающей среды и экономического развития. Энергетическая безопасность имеет значение для внутренней и внешней политики. Это означает взаимозависимость между производителем $и$ потребителем, где взаимная уязвимость и взаимная выгода являются и краткосрочными, $n$ долгосрочными. В статье систематизированы виды энергии с целью устойчивого развития: баланс экономической, социальной и экологической составляющих посредством модели циркулярной экономики, которая позволяет достичь энергетической безопасности. Первым шагом является переход от углеродной энергии (нефть, газ, уголь) к чистой энергии (солнечная энергия, энергия ветра, гидроэнергетика и т.д.). Однако, не менее важно следовать принципу энергоэффективности, который заключается в соизмерении разницы между фактически использованной энергией и общей потребленной энергией (часто более высокой из-за потерь). Принципы циркулярной экономики, направленные на достижение наиболее эфффективного использования ресурсов, являются важнейшими при разработке инновационных решений, направленных на переход к чистой энергии. Изучив различные подходы путем сравнения и аналогии, мы можем сделать вывод, что Концепция циркулярной экономики предлагает эффективные бизнес-модели для обеспечения экологически безопасного использования ресурсов, способствуя достижению целей общества в области устойчивого развития. В статье использованы исторические и статистические методы, а также системный подход к изучению экономических явлений, который позволил выявить взаимосвязь между всеми элементами и их ролью в общем функционировании циркулярной экономики. Используя метод сравнения и научное моделирование, раскрывается роль циркулярной экономики в ресурсосбережении, минимизации отходов и снижении нагрузки на окружающую среду при достижении значительных экономических и социальных результатов в области энергетической безопасности.

Ключевые слова: энергетическая безопасность, циркулярная экономика, ресурсы, энергия, экология.

JEL Classification: P48, Q43, Q56, Q57. 